\title{
Lipoproteins, Cholesterol and Phospholipids in Sera of Rabbits Following Ligation of the Common Bile Duct or Injection of Carbon Tetrachloride
}

\author{
By \\ Nobukazu Ghida \\ From the Department of Pediatrics, Faculty of Medicine, Tohoku \\ University, Sendai; Director: Prof. Ts. Arakawa \\ (Received for publication, January 31, 1963)
}

In pediatric practice it was not infrequent to meet with a difficulty in etiological diagnosis for neonatal jaundice. For example, both neonatal hepatitis and atresia of the bile duct would present similar clinical and laboratory findings of "obstructive jaundice", and while an early surgical treatment is recommended for the cases with atresia of the bile duct, the therapy for those of neonatal hepatitis will be quite different.

In the present investigation it was tried to investigate whether or not any difference of lipoprotein patterns, cholesterol and phospholipids would be found between rabbits with ligation of the common bile duct, which may be considered as an extreme case of biliary obstruction on one side and those with severe damage on hepatic parenchyma produced by carbon tetrachloride injection on the other.

\section{MATERIALS AND METHODS}

The methods for determination of cholesterol and phospholipids in serum were Zak's') and Furukawa's' methods respectively. Paperelectrophoretic analysis of serum lipoproteins was done in the same way as described in a preceding paper of mine. ${ }^{3)}$ Rabbits, weighing 2,000-2,500 g, were used in this investigation.

Method for animal experimentation: - Carbon tetrachloride, $0.5 \mathrm{cc}$ per $\mathrm{kg}$ of body weight, was injected into 4 rabbits subcutaneously for successive two days. The first blood specimen was obtained just prior to the first injection of carbon tetrachloride, and on the next day the second blood specimen was taken, immediately after which the second injection was done, and the third blood specimen was obtained on the third day after the second injection, i.e. on the fourth day of the first injection.

Ligation of the common bile duct was performed on 3 rabbits, and blood

千田 信和 
examination was done just prior to the operation for the first time, and on one and three days after the ligation.

\section{RESULTS AND DISCUSSION}

The results obtained were shown in Tables I-V. Changes in cholesterol, phospholipids and lipoprotein pattern following the injection of carbon tetrachloride and the ligation of the common bile duct will be discussed on the basis of average values for each experimental group.

TABLE I. Influence of Injection of Carbon Tetrachloride upon Cholesterol in Sera of Rabbits

\begin{tabular}{|c|c|c|c|c|c|c|}
\hline \multirow{3}{*}{$\begin{array}{c}\begin{array}{c}\text { No. of blood } \\
\text { specimens }\end{array} \\
\begin{array}{l}\text { No. of } \\
\text { rabbits }\end{array}\end{array}$} & \multirow{2}{*}{\multicolumn{2}{|c|}{\begin{tabular}{|c|} 
I \\
Before the injection \\
Cholesterol $(\mathrm{mg} / 100 \mathrm{ml})$
\end{tabular}}} & \multirow{2}{*}{\multicolumn{2}{|c|}{$\begin{array}{c}\text { II } \\
\begin{array}{c}\text { One day after the } \\
\text { first injection }\end{array} \\
\text { Cholesterol }(\mathrm{mg} / 100 \mathrm{ml})\end{array}$}} & \multirow{2}{*}{\multicolumn{2}{|c|}{\begin{tabular}{|c} 
III \\
$\begin{array}{c}\text { 3 days after the } \\
\text { second injection }\end{array}$ \\
Cholesterol $(\mathrm{mg} / 100 \mathrm{ml})$
\end{tabular}}} \\
\hline & & & & & & \\
\hline & Total & Free (\%) & Total & Free (\%) & Total & Free (\%) \\
\hline $\begin{array}{c}3 \\
4 \\
6 \\
7 \\
\text { Average }\end{array}$ & $\begin{array}{r}168 \\
75 \\
58 \\
110 \\
102\end{array}$ & $\begin{array}{l}23(13) \\
25(33) \\
25(43) \\
52(46) \\
31(30)\end{array}$ & $\begin{array}{l}58 \\
45 \\
40 \\
85 \\
57\end{array}$ & $\begin{array}{l}48(82) \\
40(88) \\
10(20) \\
28(33) \\
31(55)\end{array}$ & $\begin{array}{r}83 \\
103 \\
78 \\
178 \\
110\end{array}$ & $\begin{array}{l}45(54) \\
93(90) \\
53(67) \\
65(36) \\
64(61)\end{array}$ \\
\hline
\end{tabular}

TABLE II. Influence of Injection of Carbon Tetrachloride upon Phospholipids in Sera of Rabbits

\begin{tabular}{c|c|c|c}
\hline $\begin{array}{c}\text { No. of blood } \\
\text { specimens }\end{array}$ & $\begin{array}{c}\text { I } \\
\text { Before the injection }\end{array}$ & $\begin{array}{c}\text { II } \\
\text { One day after the } \\
\text { first injection }\end{array}$ & $\begin{array}{c}\text { III } \\
\text { 3 days after the } \\
\text { second injection }\end{array}$ \\
\hline No. of rabbits & $\begin{array}{c}\text { Phospholipids } \\
(\mathrm{mg} / 100 \mathrm{ml})\end{array}$ & $\begin{array}{c}\text { Phospholipids } \\
(\mathrm{mg} / 100 \mathrm{ml})\end{array}$ & $\begin{array}{c}\text { Phospholipids } \\
(\mathrm{mg} / 100 \mathrm{ml})\end{array}$ \\
\hline 3 & 105 & 105 & 107 \\
4 & 115 & 125 & 167 \\
6 & 65 & 32 & 177 \\
7 & 86 & 43 & 130 \\
\hline Average & 92 & 76 & 72 \\
\hline
\end{tabular}

Cholesterol (cf. Fig. 1): - Total cholesterol did not show remarkable changes within 3 days after the bile duct ligation, while, in the case of carbon tetrachloride injection, it showed a marked decrease on the next day and rose slightly above the preinjection level. The ratio of free to total cholesterol increased in both experimental groups and more conspicuously in the case of the bile duct ligation. 
TABLE III. Influence of Injection of Carbon Tetrachloride upon Lipoproteins in Sera of Rabbits

\begin{tabular}{|c|c|c|c|c|c|c|c|c|c|c|c|c|c|c|c|}
\hline $\begin{array}{l}\text { No. of blood } \\
\text { specimens }\end{array}$ & \multicolumn{5}{|c|}{ I } & \multicolumn{5}{|c|}{$\begin{array}{l}\text { II } \\
\text { One day after the } \\
\text { first injection }\end{array}$} & \multicolumn{5}{|c|}{$\begin{array}{c}\text { III } \\
3 \text { days after the } \\
\text { second injection }\end{array}$} \\
\hline \multirow{2}{*}{$\begin{array}{l}\text { No. of } \\
\text { rabbits }\end{array}$} & \multicolumn{3}{|c|}{$\begin{array}{l}\text { Lipoproteins } \\
(\%)\end{array}$} & \multirow[t]{2}{*}{$\alpha / \beta$} & \multirow{2}{*}{$\alpha / \gamma$} & \multicolumn{3}{|c|}{ Lipoproteins } & \multirow{2}{*}{$\alpha / \beta$} & \multirow{2}{*}{$a / \gamma$} & \multicolumn{3}{|c|}{$\begin{array}{c}\text { Lipoproteins } \\
(\%)\end{array}$} & \multirow{2}{*}{$\alpha / \beta$} & \multirow{2}{*}{$\alpha / \gamma$} \\
\hline & $a$ & $\beta$ & $\gamma$ & & & $\alpha$ & $\beta$ & $\gamma$ & & & $\alpha$ & $\beta$ & $\gamma$ & & \\
\hline 3 & 3.9 & 24.1 & 42.0 & 1.41 & 0.80 & 12.8 & 31.7 & 55.5 & 0.40 & 0.23 & 25.3 & 45.8 & 28.9 & 0.55 & 0.8 \\
\hline 4 & 37.4 & 44.6 & 18.0 & 0.84 & 2.07 & 12.2 & 34.1 & 53.7 & 0.36 & 0.20 & 14.4 & 54.2 & 31.4 & 0.27 & 0.48 \\
\hline 6 & 30.3 & 41.9 & 27.8 & 0.72 & 1.35 & 17.4 & 37.6 & 45.0 & 0.46 & 0.38 & 4.4 & 66.7 & 28.9 & 0.07 & 0.15 \\
\hline 7 & 21.6 & 39.9 & 38.4 & $\mid 0.54$ & 0.56 & 25.4 & 37.5 & 37.1 & 0.68 & 0.68 & 9.7 & 61.9 & 28.4 & 0.16 & 0.34 \\
\hline Average & 30.8 & 37.6 & & 0.87 & 1.19 & 16.9 & 35.2 & 47.8 & 0.47 & 0.37 & 13.4 & 57. 1 & 29.4 & 0.26 & 0.46 \\
\hline
\end{tabular}

TABLE IV. Influence of Ligation of the Common Bile Duct upon Cholesterol and Phospholipids in Sera of Rabbits

\begin{tabular}{|c|c|c|c|c|c|c|c|c|c|}
\hline \multirow{2}{*}{$\begin{array}{l}\text { Conditions } \\
\text { at the } \\
\text { time of } \\
\text { blood } \\
\text { sampling }\end{array}$} & \multirow{2}{*}{\multicolumn{3}{|c|}{ Before the ligation }} & \multicolumn{6}{|c|}{ After ligation of the common bile duct } \\
\hline & & & & & One $d$ & day & & Three o & days \\
\hline \multirow{2}{*}{$\begin{array}{l}\text { No. of } \\
\text { rabbits }\end{array}$} & \multicolumn{2}{|c|}{$\begin{array}{l}\text { Cholesterol } \\
(\mathrm{mg} / 100 \mathrm{ml})\end{array}$} & \multirow{2}{*}{$\begin{array}{c}\text { Phospholi- } \\
\text { pids } \\
(\mathrm{mg} / 100 \mathrm{ml})\end{array}$} & \multicolumn{2}{|c|}{$\begin{array}{l}\text { Cholesterol } \\
(\mathrm{mg} / 100 \mathrm{ml})\end{array}$} & \multirow{2}{*}{$\begin{array}{l}\text { Phospholi- } \\
\text { pids } \\
(\mathrm{mg} / 100 \mathrm{ml})\end{array}$} & \multicolumn{2}{|c|}{$\begin{array}{c}\text { Cholesterol } \\
(\mathrm{mg} / 100 \mathrm{ml})\end{array}$} & \multirow{2}{*}{$\begin{array}{l}\text { Phospholi- } \\
\text { pids } \\
\text { (mg/100 ml }\end{array}$} \\
\hline & Total & Free(\%) & & Total & Free (\%) & & Total & Free(\%) & \\
\hline 8 & 120 & $50(41)$ & & 103 & $68(66)$ & 92.5 & 89 & $78(87)$ & 52.1 \\
\hline 9 & 55 & $25(45)$ & & 90 & $88(97)$ & 83 & 125 & $125(100)$ & 92.5 \\
\hline 10 & 80 & $35(43)$ & 64.8 & 50 & $50(100)$ & 55.5 & 45 & $45(100)$ & 111.1 \\
\hline Average & 85 & $36(43)$ & 57.6 & 81 & $68(87)$ & 77.1 & 86.3 & $382(96)$ & 85.2 \\
\hline
\end{tabular}

TABLE V. Influence of Ligation of the Common Bile Duct upon Lipoproteins in Sera of Rabbits

\begin{tabular}{|c|c|c|c|c|c|c|c|c|c|c|}
\hline $\begin{array}{l}\text { Conditions at } \\
\text { the time of } \\
\text { blood sampling }\end{array}$ & \multicolumn{5}{|c|}{$\begin{array}{l}\text { Before ligation of the } \\
\text { common bile duct }\end{array}$} & \multicolumn{5}{|c|}{$\begin{array}{l}\text { Three days after ligation of } \\
\text { the common bile duct }\end{array}$} \\
\hline \multirow{2}{*}{ No. of rabbits } & \multicolumn{3}{|c|}{ Lipoproteins (\%) } & \multirow{2}{*}{$\alpha / \beta$} & \multirow{2}{*}{$\alpha / \gamma$} & \multicolumn{3}{|c|}{ Lipoproteins (\%) } & \multirow{2}{*}{$\alpha / \beta$} & \multirow{2}{*}{$\alpha / \gamma$} \\
\hline & $a$ & $\beta$ & $\gamma$ & & & $\alpha$ & $\beta$ & $\gamma$ & & \\
\hline 8 & 17.4 & 49.8 & 32.8 & 0.3 & 0.8 & 19.4 & 62.0 & 18.5 & 0.31 & 1.05 \\
\hline 9 & 24.7 & 46.5 & 30.8 & 0.53 & 0.80 & 14.1 & 72.5 & 13.4 & 0.19 & 1.05 \\
\hline 10 & 22.1 & 48.6 & 29.3 & 0.45 & 0.75 & 16.4 & 54.0 & 29.6 & 0.30 & 0.55 \\
\hline Average & 21.3 & 48.3 & 30.9 & 0.44 & 0.69 & 16.6 & 62.8 & 20.5 & 0.26 & 0.88 \\
\hline
\end{tabular}




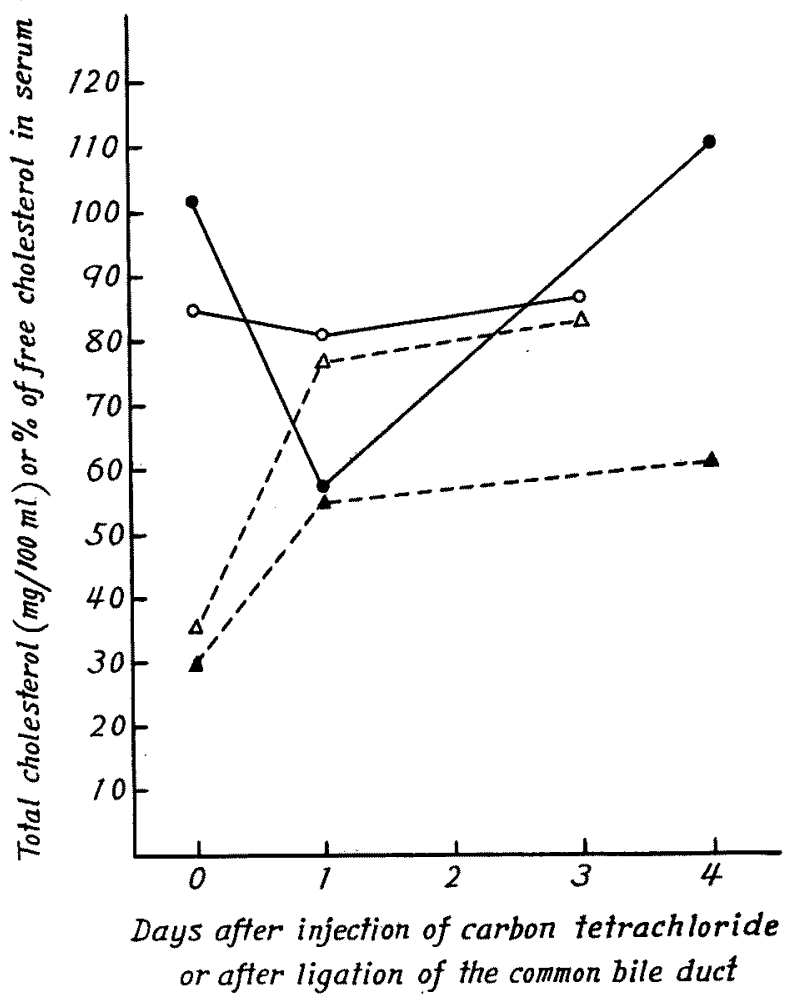

Fig. 1. Serum cholesterol following the bile duct ligation and following injection of carbon tetrachloride in rabbits.

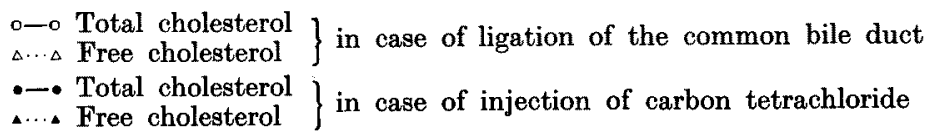

Phospholipids (cf. Fig. 2): - A steady increase in phospholipids in serum was found in case of the bile duct ligation, while, in case of carbon tetrachloride injection, a marked increase in phospholipids was attained on the 4th day after the first injection, accompanied by a marked decrease on the next day of the first injection.

Lipoprotein pattern (cf. Fig. 3): - A decrease in $\alpha$-lipoprotein associated with an increase in $\beta$-lipoprotein was found in both the experimental groups, but it was worthy of note that the change in $\gamma$-lipoprotein differed in each group, that is, a decrease in $\gamma$-lipoprotein was observed in case of the bile duct ligation, while no change in this fraction was seen in case of the carbon tetrachloride injection. This relation was more clearly demonstrated in Fig. 3, in which the ratio of $\alpha$-to $\gamma$-lipoportein $(\alpha / \gamma)$ did not decrease, but tended to increase in case of the 


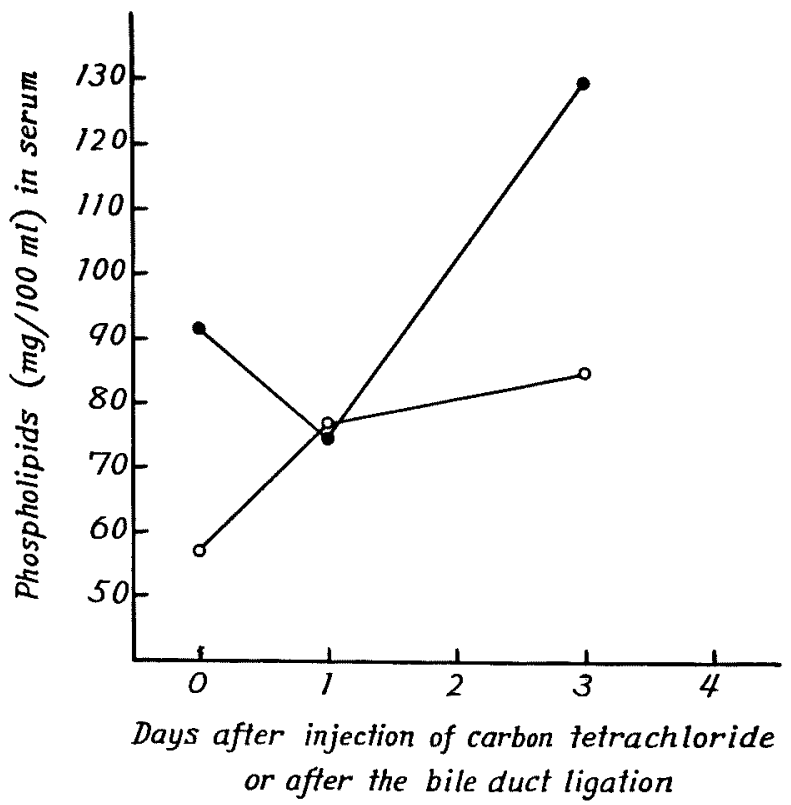

Fig. 2. Serum phospholipids following the bile duct ligation and following injection of carbon tetrachloride in rabbits.

$0-0:$ in case of the bile duct ligation

- - : in case of injection of carbon tetrachloride

bile duct ligation on one hand, and the $\alpha / \gamma$ ratio decreased markedly in case of the carbon tetrachloride injection on the other hand.

In rats with the ligation of bile duct Chanutin and Ludewig ${ }^{4}$ ) demonstrated an increase in serum free cholesterol with no increase in ester cholesterol and an increase in phospholipids proportional to the increase in free cholesterol. Hawkins and Wright ${ }^{5}$ ) reported, however, that in dogs the ligation of the common bile duct caused an increase in the absolute amount of cholesterol ester which paralleled to the hypercholesteremia and that cholesterol ester was reduced in these animals only after superimposing added damage by an administration of chloroform.

In 1950 Albrink et al., $\left.{ }^{6}\right)$ basing upon clinical investigations of hepatitis and obstructive jaundice, reported that the ratio of free to total cholesterol rose markedly in both conditions and that the total cholesterol was the lowest where the element of parenchymal damage was the greatest, that is, in severe infectious hepatitis, and further that it was higher where the element of obstruction was the greatest, in prolonged biliary obstruction.

In 1955 Eder et al..$^{j)}$ reported the results of clinical investigation into biliary cirrhosis, obstructive jaundice and acute hepatitis, in which a decrease in $a$ - 


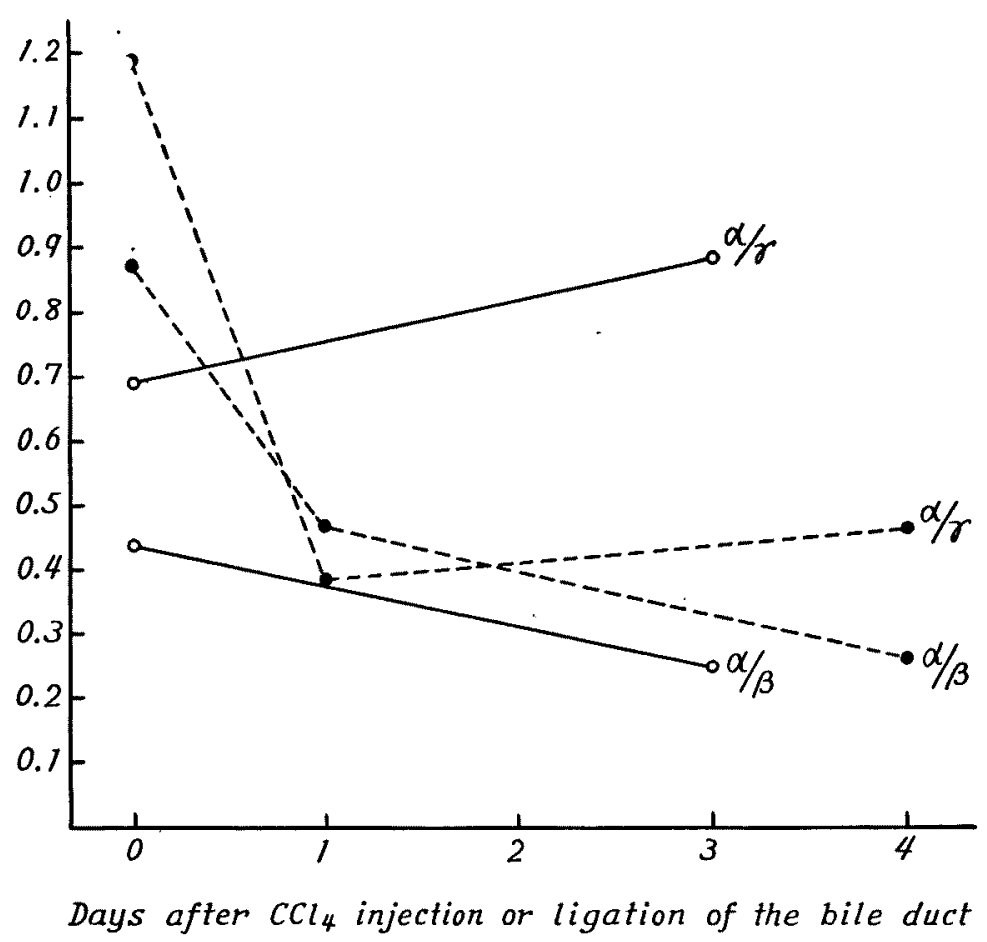

Fig. 3. The ratios of $\alpha / \beta$ and of $\alpha / \gamma$ in sera from rabbits with $\mathrm{CCl}_{4}$ injection or ligation of the common bile duct.

$0-0$ : Rabbits with ligation of the common bile duct

-... : Rabbits with the $\mathrm{CCl}_{4}$ injections

lipoprotein associated with an increase in $\beta$-lipoprotein was observed paperelectrophoretically in all these conditions. Furthermore they carried out chemical fractionation of plasma protein by using Cohn's method and found an occurrence of abnormal lipoprotein of which a high level was found in obstructive jaundice but not in hepatitis.

A finding to be noticed in my experimentation is the change in $\gamma$-lipoprotein, that is, $\gamma$-lipoprotein was decreased markedly following the bile duct ligation, but did not decrease following the carbon tetrachloride injection. Most part of lipids in $\gamma$-lipoprotein consisted of triglyceride and chylomyclon ${ }^{8)}$ which were derived from dietary fat. It was therefore easily acceptable that an impaired absorption of dietary fat from intestine due to block of the bile flow by the bile duct ligation brought about a decrease in $\gamma$-lipoprotein in serum.

\section{SUMMARY AND CONCLUSIONS}

An increase in total cholesterol, the ratio of free to total cholesterol and 
phospholipids and a decrease in the ratio of $\alpha$-to $\beta$-lipoprotein in serum were observed similarly in both experimental conditions of rabbits - the bile duct ligation and the injection of carbon tetrachloride. But a decrease in $\gamma$-lipoprotein was observed in case of the bile duct ligation only, but not in case of the injection. of carbon tetrachloride.

\section{References}

1) Zak, B. et al., Am. J. Med. Technol., 1957, 23, 283.

2) Furukawa, M. et al., Seikagaku, (Jap.), 1952, 24, 76.

3) Chida, N., in press in this Journal.

4) Chanutin, A. \& Ludewig, S., J. Biol. Chem., 1936, 115, 1.

5) Hawkins, W.B. \& Wright, A., J. Exp. Med., 1934, 59, 427.

6) Albrink, M. J. et al., J. Clin. Inv., 1950, 29, 781.

7) Eder, H.A. et al., ibid., 1955, 34, 1147.

8) Knorr, D. \& Wehrheim, I.E., Zeitschr. f. K.H.K., 1961, 85, 308. 